\title{
Ultrasound in transition - sonographers and student sonographers in Austria
}

\author{
Ultraschall im Umbruch - Sonografer und Studenten-Sonografer in Österreich
}

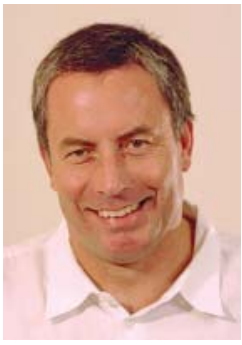

Gerhard Mostbeck

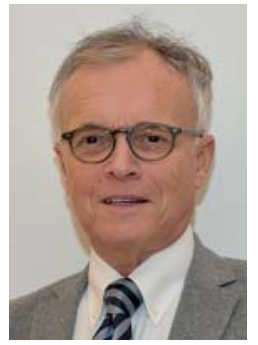

Hermann Kathrein

\section{The past}

Ultrasound pioneers come from many different countries and from various areas of specialization so that the organization of US is highly heterogeneous in medical fields in Europe as well as around the world $[1,2]$. This is also reflected in the scientific representation of US that is traditionally organized in AT, DE, and $\mathrm{CH}$ in large interdisciplinary US societies (Austrian Society of Ultrasound in Medicine (ÖGUM), German Society of Ultrasound in Medicine (DEGUM), Swiss Ultrasound Society in Medicine (SGUM)). US is an integrative part of the student curriculum of Austrian medical universities and also an integrative part of physician training in many areas of specialization in accordance with the "new" training regulations from 2015.

\section{The present - what does US mean to you?}

A provocative question? In 2018, we can no longer dismiss US as "you know, US". In addition to real-time US in 2D, 3D, and 4D, the Doppler techniques, elastography and contrast-enhanced US (CEUS) are currently also available and are referred to collectively as "multiparametric US" - similar to "multiparametric MRI". Moreover, the broad availability of the technique as a result of portable devices, the targeted use of US in certain clinical issues ("point-of-care US", e. g. FAST in trauma patients), data fusion of US with MRI/CT/PET, and many other technical and organizational aspects play an increasingly important role. Today, you can buy a high-end US device for more than $€ 100000$ or you can order a probe and app for your smartphone on the Internet for less than $€ 200$. With both versions, you can presumably detect the liver,

\author{
Correspondence \\ Univ. Prof. Dr. Gerhard Mostbeck \\ Kaasgrabengasse 17, A-1190 Wien \\ gerhard.mostbeck@chello.at \\ Prim. a.D. Univ. Prof. Dr. Hermann Kathrein \\ Sonnseite 12, A-6130 Schwaz \\ hermann.kathrein@chello.at \\ Bibliography \\ DOI https://doi.org/10.1055/a-0593-8343 \\ Published online: 2018 \\ Ultraschall in Med 2018; 39: 253-258 \\ (c) Georg Thieme Verlag KG, Stuttgart · New York \\ ISSN 0172-4614
}

gallbladder, thyroid gland, and abdominal aortic aneurysms. But does this mean that both versions are equal? Therefore, US should be viewed in accordance with the broad range of medical techniques and diagnostic possibilities. Consequently, the complexity of the method also requires varying levels of continuing education and advanced training.

\section{The present - how is US taught in Austria?}

US is an integrative part of training in many specialties (Training Regulation for Physicians 2015; see: http://www.aerztekammer. at/arzte-ausbildungsordnung). Since 2015, a 9-month period of basic training is followed by basic education and specialized training in the chosen area of specialization. The required knowledge and skills regarding diagnostic US imaging are defined for many areas but technical aspects (multiparametric US) have not been further defined. However, examination numbers (= examinations personally performed and documented under supervision) have been recorded and are required for board certification. Examples: Basic radiology education: $n=1500$ examinations of all organs, incl. Doppler US. Module 5, abdomen: $n=600$ abdominal US examinations, $\mathrm{n}=200$ kidney US scans incl. duplex and small-part US. Internal medicine - gastroenterology: $n=150$ abdominal US scans in basic education, $n=350$ abdominal US scans and $n=30$ "punctures" in specialized training. Basic urology education: $n=500$ "subspeciality-specific" ultrasound scans.

A consequence of this development in some departments is the realization that the required number of US cases cannot be achieved because: 
- Trainers do not or only partially have the necessary US competence and qualifications, and the time resources of trainers are often limited,

- US devices are lacking and/or outdated,

- The number of patients for indicated US examinations is limited,

- Or a combination of these limitations prevents these case numbers from being met.

"Interdisciplinary US centers" were established in the past at only a few hospitals in Austria. This type of organization guarantees high-quality and economical US care for patients and ensures interdisciplinary US training [3]. "New” US devices are currently being requested at many training centers because devices with low utilization and a lack of documentation options are often present. Summary of the "new training regulation" for diagnostic US imaging: Unsatisfactory physicians in training in various areas of specialization, overworked US trainers, and major difficulty achieving the required number of US examinations for board certification. An additional US investment requirement must also be taken into consideration.

\section{The present - who actually performs US examinations?}

Traditionally, US is viewed as the modern stethoscope, as an extension of the medical examination arm, and as part of a comprehensive clinical examination. Perhaps portable smartphone US devices will one day hang around the necks of young physicians as the stethoscope once did. US is performed directly at the patient's bedside. The examiner is able to talk to, touch, see, and communicate with the patient. Combining all of this data provides the examiner with much more information than the US images alone can show. The examiner is challenged, even physically, develops one diagnosis and rejects another, and makes decisions directly at the patient's bedside since the examination, unlike CT and MRI, "cannot be comprehensively documented and readily reproduced". "Classic" US-oriented internists repeatedly told radiologists that only "clinically" trained physicians - and not radiologists with their "images and devices" - should perform examinations. Perhaps the idea of performing US directly at the bedside of sick, possibly bad smelling, uncooperative patients was and is one of the reasons why US compared to CT and MRI (...just sitting in front of a console) became increasingly less "sexy" among many young radiologists and technical US developments were not adopted or only with a delay. This is also true for other areas of specialization. CEUS, which is still not sufficiently available and is not reimbursed by the social security system in private practices is used as an example here.

US is not universally performed by physicians directly at the patient's bedside [1, 2, 4]. An editorial by P.S. Sidhu and H.M. Edwards in the European Journal of Ultrasound in 2017 was the subject of serious debate [4 - 7]. In some European countries, ultrasound assistants ("sonographers") perform US examinations and draw conclusions. In the USA, sonographers acquire "US images" that are then interpreted by a physician/radiologist. In Aus- tralia, sonographers perform US examinations in many areas and create reports. One of the best presentations on sonoanatomy of the neck organs ever heard by GM was held by a sonographer at the US world congress WFUMB 2010 in Sydney, Australia. HK received some of his basic duplex sonography training from a sonographer in the USA. Training of this professional group in these countries is comprehensively legally regulated, is supported by the professional societies, and takes several years. In Europe, some sonographers do not have a medical background and then only work together with certain specialists. However, postgraduate training with exams and certification is often required.

Non-physician healthcare professionals with varying degrees of basic ultrasound training have been working in Austria already for a number of years. This includes the examination of brain-supplying arteries, prenatal US testing, and US examination of the abdomen primarily in private practices and at institutes with various areas of specialization. Little is known about the medical or nonmedical background and qualifications of these healthcare professionals. No one can honestly believe that only physicians are capable of performing duplex sonography of the neck arteries or US screening for aortic aneurysms. The desire to introduce a "sonographer" professional group has consequently been repeatedly discussed for many years in the boards and committees of the ÖGUM, DEGUM and SGUM. The discussion has always been very lively with the prevailing opinion being that ultrasound should be performed by physicians and US examination requires comprehensive medical expertise beyond US knowledge of a "specific organ". Physicians in private practice were concerned that reimbursement for US services could become even lower in the event of US examinations no longer being performed by physicians at the patient's bedside.

\section{The future - moving away from US being performed by physicians?}

\section{"Student sonographers"}

"Student sonographers" (those studying medicine, often at the end of their studies, frequently acting as tutors in US courses, knowledge and skills comparable to those gained from a completed basic US course, often very dedicated and motivated) are used by various specialists (largely internists) as paid representatives in private practices to perform and document US examinations (currently performed in approximately 15 private practices in Vienna, increasing tendency and demand, presumably other unknown cases, etc.). These examinations (US neck, abdomen, vessels, echocardiography) are then interpreted by the private practice owners or specialists based on the image and/or video documentation. Student sonographers are motivated, learn by doing (and are often "better" than private practice owners according to rumors) and earn money. The goal is not (just) to train dedicated students (subinternship, internship) but also to relieve private practice owners of the need to perform time-intensive (and poorly reimbursed) diagnostic US imaging. However, there are many unanswered questions: Certification of student sonographers, liability and informed consent, legality of outsourcing contractual 
services with the social insurance agencies, and finally whether it is acceptable for students to act as representatives of specialists when the medical chambers clearly forbid this for residents.

\section{Ultrasound for radiologic technologists}

As part of its continuing education program, the Austrian Society of Radiologic Technologists offers advanced training modules in ultrasound for radiologic technologists "based on the occupational profile and on the professional qualifications according to MTDG 460/1992 idgF" (refer to: https://www.radiologietechnologen. at/bildung/sonographer), in cooperation with the University of Applied Sciences Wiener Neustadt and approved, according to the website of the Austrian Society of Radiologic Technologists, by an order of the state of Lower Austria in January 2017 (GS4GB 3/493-2016). Almost the entire field of diagnostic US imaging is supposed to be taught in 8 2-day fee-based modules (basic module, abdomen, orthopedics and infant hip, thyroid and vessels, breast, echocardiography, gynecology and obstetrics, emergency medicine). "Expanding upon the basic module, participants acquire advanced knowledge and skills in the field of abdominal ultrasound. After completion of the module, participants are able to independently perform ultrasound examinations of the abdomen and to write an evaluation report regarding patient status and image documentation. Participants develop their analytical thinking and can determine plausibilities.... For the organ modules, clinical internships in at least 4 module areas are required and at least 700 validated evaluations (case analyses) must be documented". However, the association's website does not specify where these internships are to take place and who is supposed to validate at least 700 evaluations.

This led to discussions in medical circles. Is an "evaluation report" supposed to replace the physician's report? Independent examining can be learned in 2 days, theoretically, just like that, even though the medical training regulations from 2015 were expanded to include large numbers of US cases (see above)? US internships are being sought for radiologic technologists even though medical training in US in all areas of specialization is already difficult.

Of course, with appropriate multi-year training, people both with and without a background as a "healthcare professional" can be capable of performing US examinations for specific medical issues. The question is whether the introduction of very short module-based training as offered by the Austrian Society of Radiologic Technologists is a suitable training method. In the authors' opinion, the answer is no. Former ÖGUM-President Univ. Prof. Dr. Andrea Klauser, Univ. Prof. Dr. Christian Herold (ÖRG President) and Dr. Klaus Wicke (Chairman of BURA) already issued a joint statement regarding this training program that states that ÖGUM does not support this training program and insists that every - even indirect - reference to ÖGUM must be removed from all official statements.

With respect to healthcare policy, it must be discussed whether the introduction of a "sonographers" professional group would be useful and desired in the Austrian healthcare system, what training this group would need, and which qualifications would be required. Chambers and professional societies should be inclu- ded in this discussion. Who would bear responsibility for US services in this environment has not yet been clarified. Role distribution between sonographers and physicians would also need to be clarified in order to ensure that responsibilities with respect to patients are met.

From a physician's standpoint, it seems very strange that the efforts of the Austrian Society of Radiologic Technologists to create a short sonographer training program are coming at a time when medical training in diagnostic US imaging was just redefined in Austria and requires high qualitative and quantitative knowledge and skills. A large Viennese hospital operator is also attempting to train its radiologic technologists in US as if there wouldn't be any conflict with continuing medical education and advanced training in US. It is also odd that the radiology group of the Vienna Medical Chamber "fully supports" these efforts by the Austrian Society of Radiologic Technologists and is highly involved in the US training program of the Austrian Society of Radiologic Technologists and other special interest groups. The fact that this is in conflict with their "own" Austrian Medical Chamber certification guidelines for ultrasound (https://www.arztakademie.at/fileadmin/template/main/OeAeKDiplomePDFs/Diplom-Richtlinien/ RL11_Sonographie.pdf) from 2011 is apparently unimportant. What are their objectives and motives? It cannot simply be the desire to use radiologic technologists and student sonographers in private practice because they are cheaper than specialists or the desire to have cheaper radiologic technologist sonographers take over ultrasound services currently performed by physicians in hospitals.

However, one reason for these actions can be definitively ruled out: Improvement of the quality of ultrasound care for patients!

NOTES:

- A version of the article expanded and adapted by G. Mostbeck was published in electronic form under News 1/2018 on the website of the Austrian Society of Radiology (http://www.oerg.at/).

- H. Kathrein is the current president of the Austrian Society of Ultrasound in Medicine (ÖGUM).

\section{Ultraschall im Umbruch - Sonografer und Studenten-Sonografer in Österreich}

\section{Die Vergangenheit}

US-Pioniere stammen innerhalb und außerhalb Europas aus unterschiedlichen Fachbereichen, sodass US sehr heterogen in medizinischen Fächern in Europa, aber auch weltweit, verortet ist [1, 2]. Das spiegelt sich auch in der wissenschaftlichen Vertretung des US, die in AT, DE und $\mathrm{CH}$ in mitgliederstarken, interdisziplinären US-Gesellschaften (ÖGUM, DEGUM, SGUM) traditionell organisiert ist. US ist ein integrativer Bestandteil des studentischen Curriculums österreichischer Medizinuniversitäten und integrativer 
Bestandteil der Ärzteausbildung vieler Fächer nach der „neuen“ Ausbildungsordnung von 2015.

\section{Die Gegenwart - Was verstehen SIE eigentlich unter US?}

Eine provokante Frage? Nun, wir können „US“ 2018 nicht einfach als „eh klar, klaro - US“ abtun. Neben dem Real-Time US in 2 D, 3 D und 4D stehen heute Dopplertechniken, Elastografie und KM-US (CEUS) zur Verfügung, die zusammen als „multiparametrischer US“ - ähnlich wie die „multiparametrische MRT" - bezeichnet werden. Daneben spielen aber auch die Verbreitung der Technik durch tragbare Geräte, der zielgerichtete Einsatz des US in bestimmten klinischen Fragestellungen („point-of-care-US“, z. B. FAST beim Traumapatienten), die Datenfusion von US mit MR/ $\mathrm{CT} / \mathrm{PET}$ und viele andere technische und organisatorische Aspekte eine immer größere Rolle. Sie können sich heute ein High-End-USGerät für mehr als 100000 ,- € kaufen, aber auch im Internet Schallkopf und App zu ihrem Smartphone für weniger als 200,-€ bestellen. Mit beiden Varianten können Sie vermutlich Leber und Gallenblase erkennen, können die Schilddrüse darstellen und auch ein abdominelles Aortenaneurysma detektieren. Aber ist das deshalb „derselbe“ US? Es ist also naheliegend, US ebenso differenziert zu betrachten, wie sich die Medizintechnik und die diagnostischen Möglichkeiten auch darstellen. Die Komplexität der Methode erfordert daher auch eine differenzierte Fort- und Weiterbildung.

\section{Die Gegenwart - Wie wird US in Österreich gelehrt?}

US ist integrativer Bestandteil der Ausbildung in vielen Sonderfächern (Ärzteausbildungsordnung 2015; siehe: http://www.aerztekammer.at/arzte-ausbildungsordnung). Seit 2015 erfolgt nach der 9-monatigen Basisausbildung die Ausbildung zum FA in Grund- und Schwerpunktausbildung. Die Kenntnisse und Fertigkeiten in US-Diagnostik sind für viele Fächer definiert, wobei technische Aspekte (multimodaler US) nicht weiter differenziert werden. Sehr wohl sind aber Untersuchungszahlen (= unter Supervision eigenhändig durchgeführte und dokumentierte Untersuchungen) hinterlegt und für das Facharztzeugnis gefordert. Als Beispiele: Grundausbildung Radiologie: n=1500 Untersuchungen aller Organe, inkl. Doppler-US. Modul 5, Abdomen: $n=600$ Abdomen-US, $n=200$ Nieren-US, inkl. Duplex- und small-part-US. Innere Medizin/Gastroenterologie: $n=150$ Abdomen-US in der Grundausbildung, dazu $\mathrm{n}=350$ Abdomen-US und $\mathrm{n}=30$ „Punktionen" in der Schwerpunktausbildung. Grundausbildung Urologie: $\mathrm{n}=500$ Fälle „fachspezifische“ Sonografie.

Eine Folge dieser Entwicklung ist an manchen Fachabteilungen die Erkenntnis, dass die geforderten US-Fallzahlen nicht erbracht werden können, weil:

- die Ausbildungskompetenz und Qualifikation der Ausbilder im US nicht oder nur teilweise vorhanden sind; zudem sind die zeitlichen Ressourcen der Ausbilder häufig begrenzt.

- US-Geräte fehlen und/oder veraltet sind.
- die Zahl an PatientInnen für indizierte US-Untersuchungen limitiert ist.

- eine Kombination dieser Einschränkungen die Erfüllung der Fallzahlen behindert.

Nur an wenigen Krankenhäusern in Österreich wurden in der Vergangenheit „interdisziplinäre US-Zentren“ etabliert. Diese Organisationsform garantiert eine qualitativ hochstehende, ökonomisch günstige US-Versorgung der PatientInnen und sichert die interdisziplinäre Ausbildung in der US-Diagnostik [3]. Derzeit werden an vielen Ausbildungsstätten „neue“ US-Geräte zusätzlich angefordert, wobei oft Geräte mit geringer Auslastung und mangelhaften Dokumentationsmöglichkeiten vorhanden sind. Fazit der „Ausbildungsordnung Neu“ für die US-Diagnostik: Unzufriedene Ausbildungsärzte verschiedener Fächer, überforderte ärztliche US-Ausbilder und größte Schwierigkeiten, die geforderten US-Zahlen für das jeweilige FA-Zeugnis zu erreichen! Nicht zu vergessen ist ein zusätzlicher US-Investitionsbedarf.

\section{Die Gegenwart - Wer macht eigentlich die US-Untersuchung?}

Traditionell wird US ja als modernes Stethoskop, als Verlängerung des ärztlichen Untersuchungsarms und als Teil einer umfassenden klinischen Untersuchung gesehen. Wie bisher die Stethoskope, so baumeln vielleicht bald die tragbaren Smartphone-US-Geräte um die Hälse der hoffnungsvollen Jungmedizinerlnnen, so manche Vision. Da ist schon was dran! US wird direkt am Patienten gemacht, man redet, berührt, sieht, kommuniziert und kombiniert diese Informationen - und erfährt dabei viel mehr als die „US-Bilder“ zeigen können! Man ist gefordert, auch körperlich, „erarbeitet“ sich eine Diagnose, verwirft eine andere, entscheidet direkt am Patienten, denn die Untersuchung ist nicht so wie CT und MRT „umfassend dokumentierbar und unlimitiert nachvollziehbar“! Immer wieder wurde gerade von „klassischen“ US-affinen Internisten den Radiologen vorgehalten, dass ja nur der „klinisch" ausgebildete Arzt - und nicht der Radiologe mit seinen „Bildern und Geräten“ - die Untersuchung durchführen sollte. Und vielleicht war und ist für viele Jung-RadiologInnen die Tatsache, hier direkt Arbeit an kranken, evtl. nicht gut riechenden, nicht kooperativen PatientInnen zu erbringen einer der Gründe, warum US in der Radiologie im Vergleich zu CT und MRT (...lässig sitzen wir vor Konsolen...) immer weniger „sexy“ wurde und technische US-Entwicklungen nicht oder nur verzögert übernommen wurden. Das gilt ähnlich auch für andere Fächer. Als Beispiel nehmen wir hier CEUS - immer noch zu wenig verbreitet und im niedergelassenen Bereich auch nicht von den Sozialversicherungsträgern honoriert.

Nicht überall auf der Welt ist US eine ärztliche Leistung, direkt am Patienten erbracht $[1,2,4]$. Ein Editorial von Sidhu PS und Edwards HM in UiM führte 2017 zu heftigen Diskussionen [4 - 7]. In einigen europäischen Ländern führen Sonografie-AssistentInnen („Sonografer“) US-Untersuchungen durch und verfassen dazu Stellungnahmen. In den USA machen Sonografer „US-Bilder“, die dann vom Arzt/Radiologen befundet werden. In Australien machen Sonografer in vielen Bereichen US-Untersuchungen 
und erstellen Befunde. Einen der besten Vorträge zur Sonoanatomie der Halsorgane, den GM je gehört hatte, hielt beim US-Weltkongress WFUMB 2010 in Sydney/Australien ein Sonografer. HK erhielt die Basis-Ausbildung in Duplexsonografie teilweise bei einem Sonografer in den USA. Die Ausbildung dieser Berufsgruppe ist in diesen Ländern selbstverständlich umfassend gesetzlich geregelt, durch Fachgesellschaften begleitet - und mehrjährig. In Europa haben einige Sonografer keinen medizinischen Hintergrund und arbeiten dann auch nur mit bestimmten Fachärzten zusammen. Doch häufig wird eine postgraduelle Ausbildung gefordert - mit Prüfungen und Zertifizierungen.

Bereits seit vielen Jahren arbeiten auch in Österreich nichtärztliche „healtcare professionals“ unterschiedlicher Grundausbildung im Bereich Ultraschall. Dazu gehören die Untersuchung der gehirnversorgenden Arterien, das Missbildungsscreening, die US-Untersuchung des Abdomens und viele andere mehr in niedergelassenen Ordinationen und Instituten unterschiedlicher Fächer. Über den medizinischen oder nichtmedizinischen Hintergrund und die Qualifikation dieser Personen ist wenig bekannt. Niemand kann ernsthaft glauben, dass nur Ärztlnnen imstande sind, eine „Duplexsono“ der Halsarterien oder ein US-Screening nach Aortenaneurysma durchzuführen. Wünsche nach Einführung einer Berufsgruppe „Sonografer“ wurden daher seit vielen Jahren immer wieder fallbezogen auch in den Vorständen und Gremien der US-Gesellschaften ÖGUM, DEGUM und SGUM diskutiert. Die Diskussion war immer sehr angeregt, wobei die Meinungen überwogen, dass die ärztliche Leistung Ultraschall auch durch ÄrztInnen zu erbringen sei und die US-Untersuchung eine umfassende, ganzheitliche medizinische Expertise auch im Umfeld eines „spezifischen Organs“ benötigt. Und von den niedergelassenen KollegInnen war die Sorge auch immer groß, dass dann ja auch die US-Honorare noch kleiner werden könnten, wenn die US-Untersuchung am Patienten nicht durch Ärzte erfolgt.

\section{Die Zukunft - Weg von der ärztlichen US-Leistungserbringung?}

\section{„Studenten-Sonografer“}

„Studenten-Sonografer“ (Studierende im Fach Humanmedizin, oft im letzten Studienabschnitt, häufig als TutorInnen in US-Kursen tätig, Kenntnisse und Fertigkeiten vergleichbar mit einem abgeschlossenen US-Grundkurs, häufig sehr engagierte und motivierte Studierende) werden von FachärztInnen unterschiedlicher Fächer (überwiegend Internisten) als honorierte Vertreter in Ordinationen eingesetzt, um US-Untersuchungen durchzuführen und zu dokumentieren (derzeit in Wien in etwa 15 Ordinationen, Tendenz und Nachfrage steigend, vermutlich Dunkelziffer). Diese Untersuchungen (US-Hals, -Abdomen und -Gefäße, Echokardiografie) werden dann von den Ordinationsinhabern bzw. FachärztInnen anhand der Bild- und/oder Video-Dokumentation befundet. Studenten-Sonografer sind motiviert, lernen dabei (und sind oft besser als die Ordinationsinhaber - so die Gerüchte) und verdienen Geld. Es geht dabei nicht (nur) um die Ausbildung (Famulatur, Praktikum) engagierter Studierender, sondern es ist eine „Vertretungstätigkeit“, um die Ordinationsinhaber in der Durch- führung der zeitintensiven (und damit schlecht honorierten) US-Diagnostik zu entlasten. Dabei bleiben viele Fragen offen: Qualifikation der Studenten-Sonografer, Haftungs- und Aufklärungsfragen, Rechtmäßigkeit der Auslagerung von Vertragsleistungen mit den Sozialversicherungsträgern und nicht zuletzt die Frage, ob eine „Vertretungstätigkeit von Fachärzten“ von Studierenden in Ordnung ist, wo doch die Ärztekammern klar die Vertretungstätigkeit von ÄrztInnen in Ausbildung untersagen!

\section{„Sonografer für RadiologietechnologInnen“}

Der Berufsverband der RadiologietechnologInnen bietet in seinem Fortbildungskalender eine Weiterbildungs-Modulausbildung „Sonografer für RadiologietechnologInnen“ „basierend auf dem Berufsbild und aufbauend auf der Berufsberechtigung nach dem MTD-G 460/1992 idgF“ an (siehe: https://www.radiologietechnologen.at/bildung/sonographer), in Kooperation mit der FH Wiener Neustadt und bewilligt laut Website des RT-Verbandes durch einen Bescheid des Landes Niederösterreich vom Jänner 2017 (GS4-GB 3/493-2016). Dabei soll in 8 kostenpflichtigen Modulen à 2 Tage (Basismodul, Abdomen, Orthopädie und Säuglingshüfte, Schilddrüse und Gefäße, Mamma, Echokardiografie, Gynäkologie und Geburtshilfe, Notfallmedizin) das nahezu gesamte Gebiet der US-Diagnostik vermittelt werden. Für den „Kompetenzerwerb“ wird z. B. für das Modul Abdomen gendergerecht ausgeführt: „Aufbauend auf das Basismodul erreicht der/die Teilnehmer/in fortgeschrittene Kenntnisse und Fertigkeiten im Bereich Ultraschall für Abdomen. Der/die Teilnehmer/in ist nach Abschluss des Moduls in der Lage eigenverantwortlich Ultraschalluntersuchungen im Bereich Abdomen durchzuführen sowie einen Auswertungsbericht über den Patientenstatus und die Bilddokumentation zu verfassen. Er/Sie hat ein analytisches Verständnis entwickelt und kann Plausibilitäten feststellen.“ Für die „Organmodule sind klinische Praktika (Hospitation) in mindestens 4 Modulgebieten erforderlich und dazu insgesamt mindestens 700 validierte Auswertungen (Fallanalysen) zu dokumentieren“. Wo diese Praktika durchgeführt werden sollen und wer „mindestens 700 Auswertungen “ validiert, bleibt als Information auf der Website des Verbandes ungenannt.

Das hat doch zu Diskussionen in medizinisch-ärztlichen Kreisen geführt. Ein „Auswertungsbericht“ ersetzt den ärztlichen Befund? Die eigenverantwortliche Untersuchungsdurchführung kann in 2 Tagen erlernt werden, theoretisch, einfach so? Wo doch gerade die ärztliche Ausbildungsordnung 2015 um große US-Fallzahlen - siehe oben - erweitert wurde? Praktikumsplätze für US werden für RTs gesucht, wo doch gerade die ärztliche Ausbildung im US in allen Fächern schwierig ist...

Niemand kann bezweifeln, dass - mit entsprechender mehrjähriger Ausbildung - Personen mit und ohne Hintergrund eines „healthcare professionals“ US-Untersuchungen in speziellen Fragestellungen durchführen können. Die Frage ist, ob die Einführung einer sehr kurzen Modulausbildung, wie vom RT-Verband organisiert, dazu ein geeignetes Instrument darstellt - aus Sicht der Autoren nicht. Die damalige ÖGUM-Präsidentin Frau Univ. Prof. Dr. Andrea Klauser hat zusammen mit Herrn Univ. Prof. Dr. Christian Herold (Präsident der ÖRG) und Herrn Dr. Klaus Wicke (Vorsitzender der BURA) bereits eine Stellungnahme zu diesem Lehrgang 
abgegeben. Darin wurde klargestellt, dass die ÖGUM diesen Lehrgang nicht unterstützt und darauf besteht, dass jeder - auch indirekte - Hinweis auf die ÖGUM von allen Aussendungen entfernt zu werden hat.

Gesundheitspolitisch sollte diskutiert werden, ob die Einführung einer Berufsgruppe „Sonografer“ im österreichischen Gesundheitswesen sinnvoll und erwünscht ist, welche Ausbildung dazu notwendig ist und welche Qualifikationen gefordert werden. In diese Diskussion sind Kammern und wissenschaftliche Fachgesellschaften einzubinden. Derzeit sind rechtliche Aspekte der Verantwortung für US-Leistungen in diesem Umfeld ungeklärt. Und es wäre die Rollenverteilung zwischen Sonografer und Ärzten zu klären, um der jeweiligen Verantwortung den Patienten gegenüber gerecht zu werden.

Aus ärztlicher Sicht mutet es schon sehr eigenartig an, dass die Bestrebungen des RT-Berufsverbandes zu einer Art Kurz-Sonografer-Ausbildung zu einem Zeitpunkt kommen, in der die ärztliche Ausbildung in US-Diagnostik in Österreich gerade neu festgelegt wurde und hohe qualitative und quantitative Kenntnisse und Fertigkeiten erfordert. Und auch ein großer Wiener Krankenhausträger bemüht sich um die Ausbildung seiner RT-Mitarbeiterlnnen in US, als ob es keine Probleme mit der ärztlichen Fort- und Weiterbildung im US geben würde. Eigenartig auch, dass die Fachgruppe Radiologie der ÄK Wien diese Bestrebungen des RT-Verbandes „Voll unterstützt“ und in die US-Ausbildung des RT-Verbandes und anderer Interessenvertretungen massiv involviert ist. Dass dabei auch die „eigene“ ÖÄK-Zertifikatslinie Sonografie (https:// www.arztakademie.at/fileadmin/template/main/OeAeKDiplomePDFs/Diplom-Richtlinien/RL11_Sonographie.pdf) aus 2011 konterkariert wird, spielt offenbar keine Rolle. Welche Ziele und Motive dahinterstehen, darf man fragen und hinterfragen. Es wird doch nicht der Wunsch nach RT- und Studenten-Sonografern im niedergelassenen Bereich sein, die billiger als (Vertretungs-) Fachärzte zu honorieren sind - und im Spitalbereich der Wunsch nach billigeren RT-Sonografern, welche die ärztliche Sonografie ja dann übernehmen können? Es gilt die ökonomische Eigeninteressens-Unschuldsvermutung!
Eine Motivation hinter diesen Aktivitäten kann aber definitiv ausgeschlossen werden: Die Verbesserung der Qualität der sonografischen Versorgung der PatientInnen!

\section{HINWEISE:}

- Der Artikel wird in erweiterter und adaptierter Form von G. Mostbeck in den ÖRG-Mitteilungen 1/2018 in elektronischer Form auf der Website der ÖRG (http://www.oerg. at/, Österreichische Röntgengesellschaft) publiziert.

- H. Kathrein ist derzeit Präsident der Österreichischen Gesellschaft für Ultraschall in der Medizin (ÖGUM).

Literatur

[1] European Society of Radiology (ESR). International Summit 2014: Organisation of clinical ultrasound in the world. Insights Imaging 2014; 5 : $641-644$

[2] European Society of Radiology (ESR). Organisation and practice of radiologic ultrasound in Europe: a survey by the ESR Working Group on UItrasound. Insights Imaging 2013; 4: 401-407

[3] Jung EM, Stroszczynski C. Modern ultrasound diagnostic procedures in an interdisciplinary ultrasound department: challenge and opportunities for radiologists. Fortschr Röntgenstr 2016; 188: 27 - 32

[4] Sidhu PS, Edwards HM. Who's doing your scan? A European perspective on ultrasound services. Ultraschall in Med 2017; 38: 479-482

[5] Seitz K. Who's Doing Your Scan? The German Perspective on Ultrasound Services: Ultrasound is More Than a Technique, it's a Medical Art. Ultraschall in Med 2017; 38: 661-663

[6] Arning C. High-Level Carotid Ultrasound Must be Performed by a Physician. Ultraschall in Med 2017; 38: 664

[7] Degeorio D, Mifsud M, Wolstenhulme S. Letter to the editor: Who's doing your scan? A European perspective on ultrasound services by Edwards and Sidhu. Ultraschall in Med 2018; $39: 93$ 